Leaving England 
American Industry and the European Immigrant, I860-I885

British Industrialists, Steel and Hosiery, I850-I950

Invisible Immigrants: The Adaptation of English and Scottish Immigrants in Nineteenth-Century America

Emigration from Europe, I815-I9I4 


\section{Leaving England}

EsSAYS ON BRITISH EMIGRATION in The Nineteenth Century

Charlotte Erickson

Cornell University Press

ITHACA AND LONDON 


\section{Copyright (C) 1994 by Cornell University}

All rights reserved. Except for brief quotations in a review, this book, or parts thereof, must not be reproduced in any form without permission in writing from the publisher. For information, address Cornell University

Press, Sage House, $5^{12}$ East State Street, Ithaca, New York 14850.

First published 1994 by Cornell Lniversity Press.

\section{Printed in the United States of America}

$£$ The paper in this book meets the minimum requirements of the American National Standard for Information SciencesPermanence of Paper for Printed Library Materials, ANSI Z39-48-1984.

Library of Congress Cataloging-in-Publication Data

Erickson, Charlotte, 1923-

Leaving England: essays on British emigration in the nineteenth century / Charlotte Erickson.

p. $\mathrm{cm}$.

Includes index.

ISBN 0-8014-2820-3

1. British Americans-History-19th century. 2. Immigrants-United StatesHistory-19th century. 3. United States-Emigration and immigration-History19th century: 4. Great Britain-Emigration and immigration-History19th century. I. Title.

$\mathrm{E}_{184} \cdot \mathrm{B}_{7} \mathrm{E}_{744} 1994$

$304.8^{\prime}$ og $41^{\prime}$ ogo $34-$ dc2o

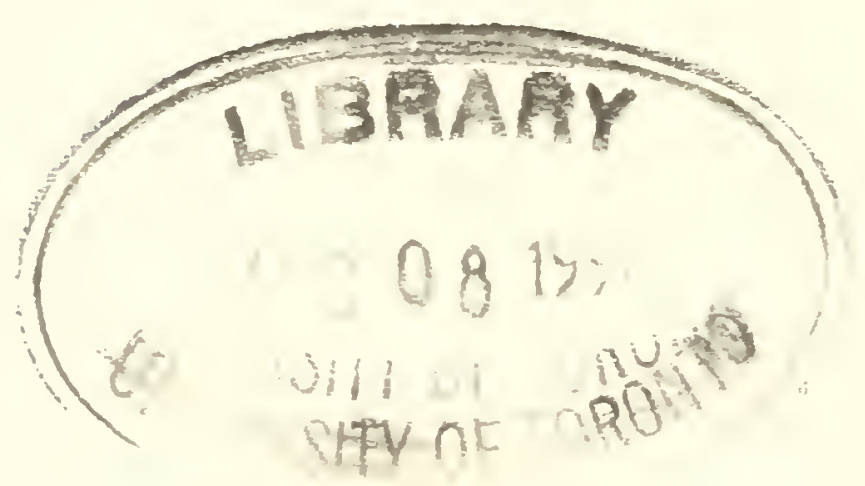


For Tom and David 
